抄

目

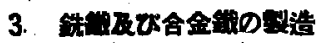

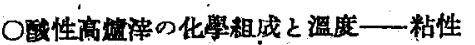

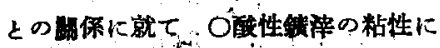

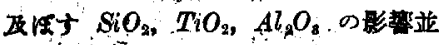

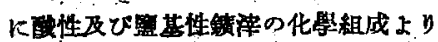

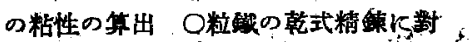
する Rennenfelt-Kalling 法

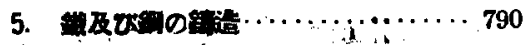
.ORandapsón 泆 ( メント整犁法)

\section{3. 銑銭及び合金鐵の製造}

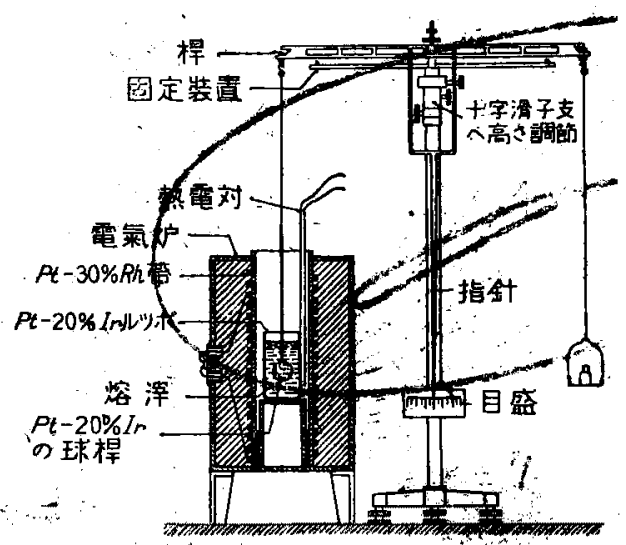

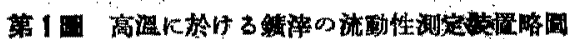

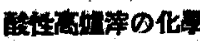

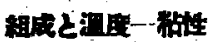 との眐保就と}

(Kurd Bndell und Rudolf Ḱley : Stahl u Eisen, Heft 23,1939)

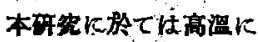

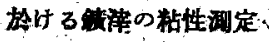
用火第1国的示如委

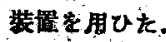

、比较㳦としては絬

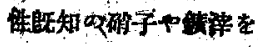

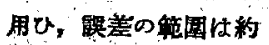
$1400^{\circ} \mathrm{C}$ - $5 \sim 150$ ) フメ゙で 土5\% 蚛市で ある。惝本試機は。

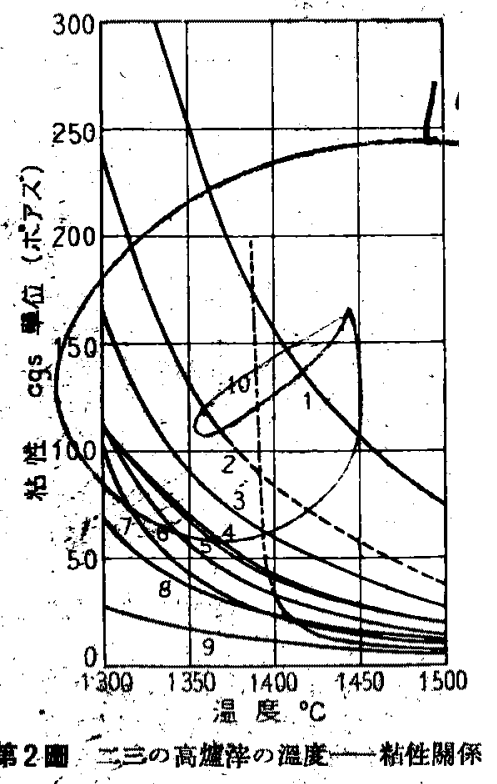

次

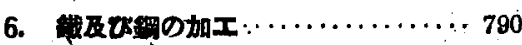

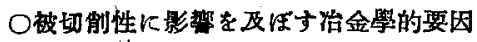

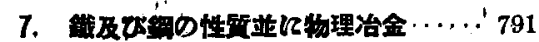
○低炭素銅の烧鈍 ○軸受用球 ○不路

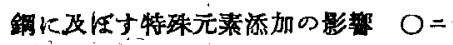
オビウムー踇合金 ○軟龬中、のアンチ。

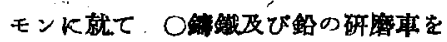

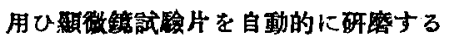
方法

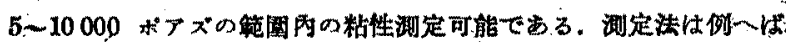

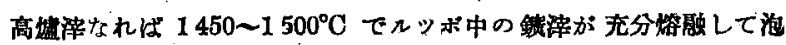

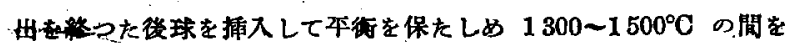

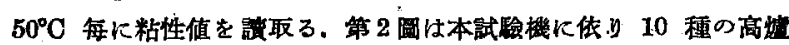

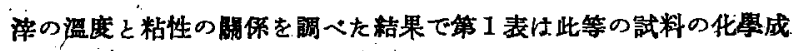

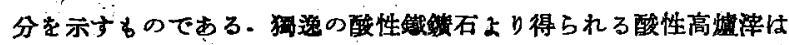
$\mathrm{CaO}: \mathrm{SiO}_{2}=0^{\circ} 4$ 迄で $<1400^{\circ} \mathrm{C}$.で粘性は<60 ボアズであるが普雨

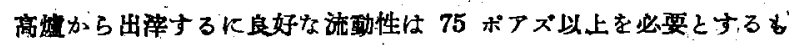
のである. 覺基性と酸性の差異は前者は $1400^{\circ} \mathrm{C}$ 以下に冷却す

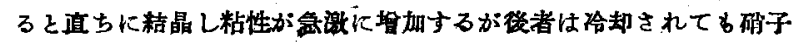

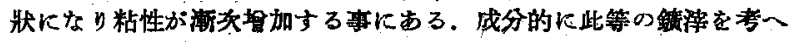

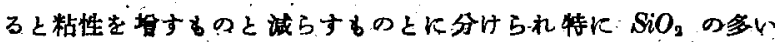

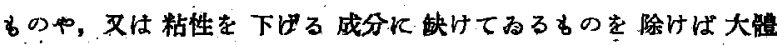

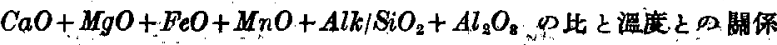

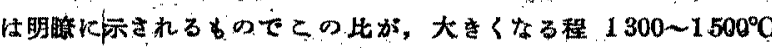

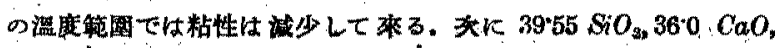

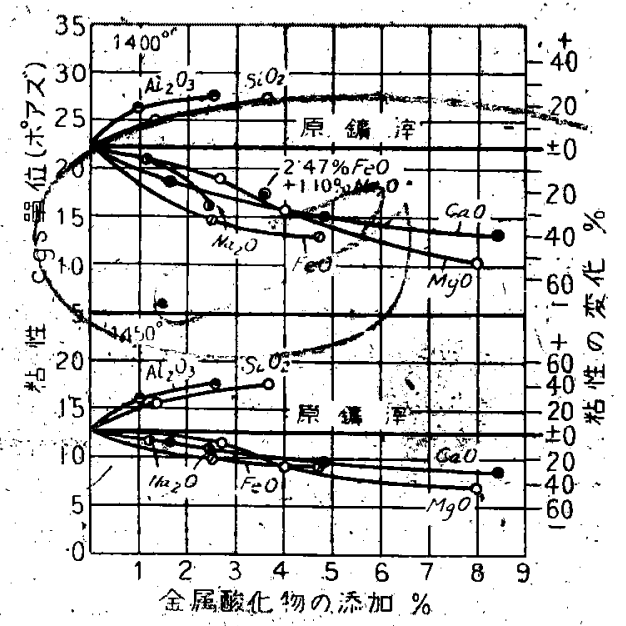

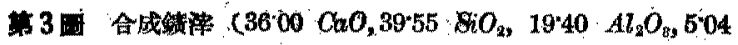

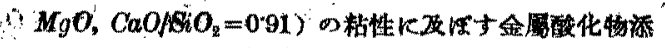

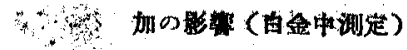




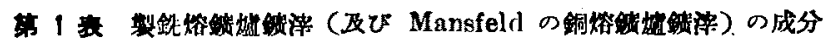

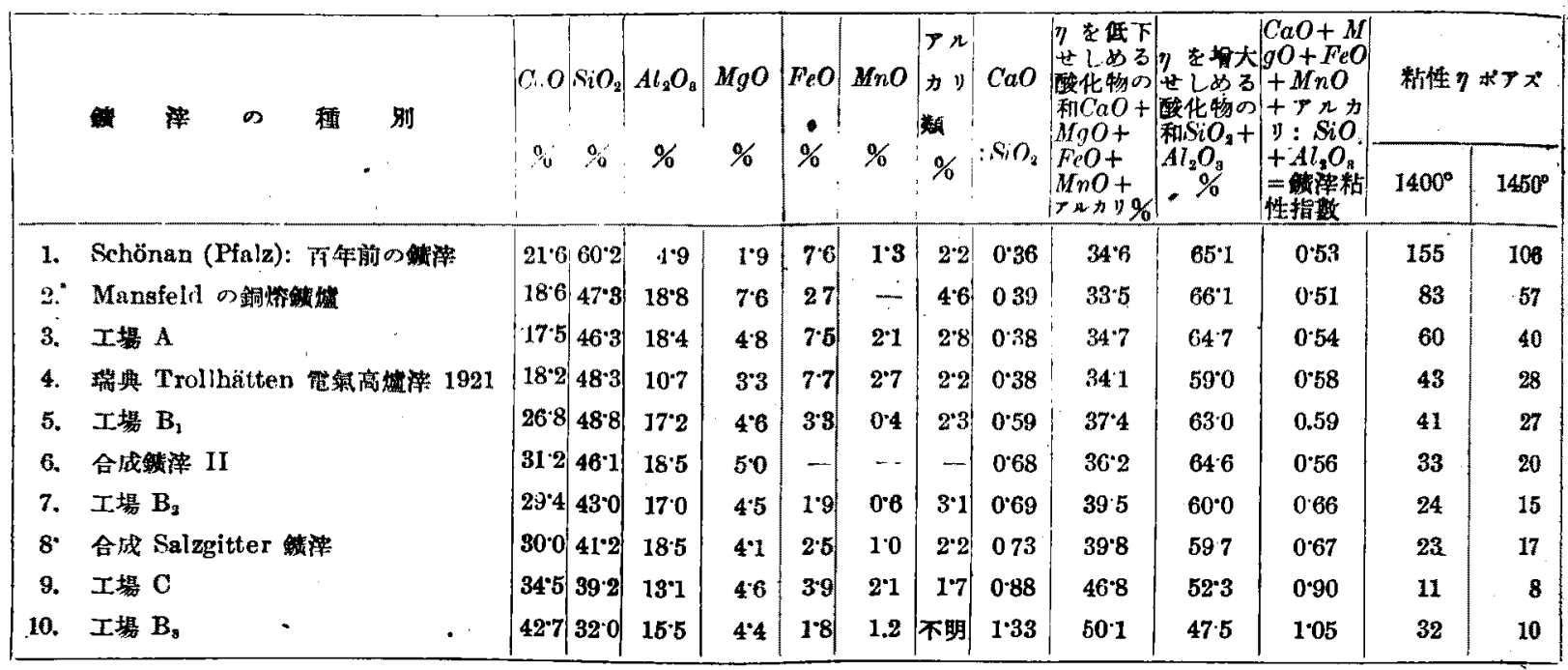

19.4 $\mathrm{Al}_{2} \mathrm{O}_{8}, 5.04 \mathrm{MgO}, \mathrm{CaO}: \mathrm{SiO}_{3}=0^{\circ} 91,46.08 \mathrm{SiO}_{3}, 31 \cdot 19 \mathrm{CaO}$,

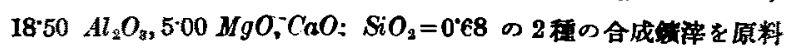

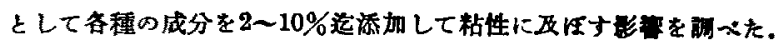

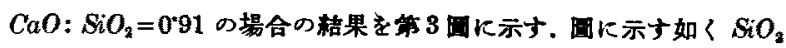
上り $\mathrm{Al}_{8} \mathrm{O}_{\mathrm{s}}$ の方が粘性を高め, $1400^{\circ} \mathrm{C}$ で㤝 $\mathrm{Na}_{9} \mathrm{O}, \mathrm{CaO}, \mathrm{MgO}$, $\mathrm{FeO}$ は少量の添加で可成粘性を下げ中でる $F_{\epsilon} O$ はとの作用最る 大で $\mathrm{MgO} 8 \%$ は $\mathrm{CaO} 8 \%$ よりとの作用大である。

抬この圆内では何れる耛晶する迄飞は至つてるない，結晶作用は

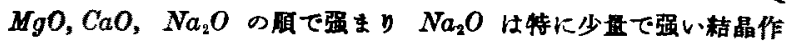
用走年ずる。

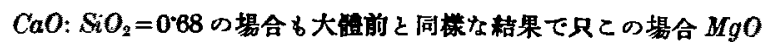
飞 $\mathrm{CaO}$ \& $\mathrm{FeO}, \mathrm{Na}_{3} \mathrm{O}$ より枮性を著しく诚少せしめる.

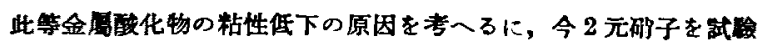
するにりチウム砂子 $\left(\mathrm{Li}_{2} \mathrm{O}: 2 \mathrm{SiO}_{2}\right)$ は $80 \% \mathrm{SiO}_{2}$, ナトリウム确子 $\left(\mathrm{Na}_{2} \mathrm{O}: 2 \mathrm{SiO}_{2}\right)$ 生 $67 \% \mathrm{SiO}_{2}$, カリウム矿子 $\left(\mathrm{K}_{2} \mathrm{O}: 2 \mathrm{SiO}_{3}\right)$ は $66 \% \mathrm{SiO}_{2}$ で方が同し温度で流動性は $\mathrm{Hi}_{2} \mathrm{O}: 2 \mathrm{SiO}_{2}$ が最食で

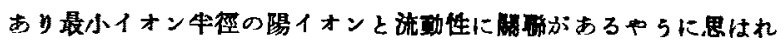

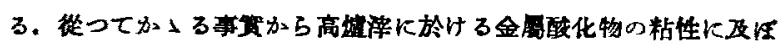

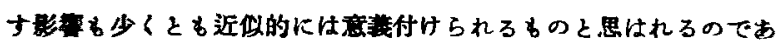

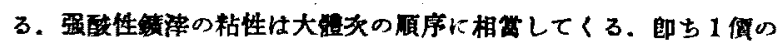
+イオンは $K, N a$ では $K^{+}<N a+(1$ ン牛徑 1+33 $\AA>0.98 \AA)$

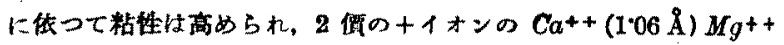

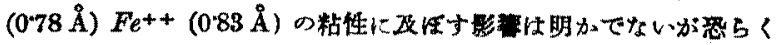

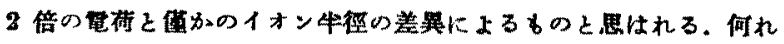

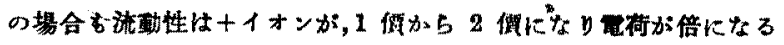

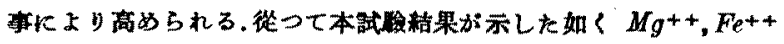

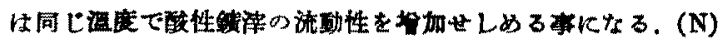

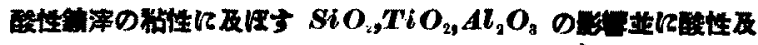

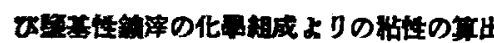

(Von Kurd und Günter Brinkmann: Stahl u. Eisen,

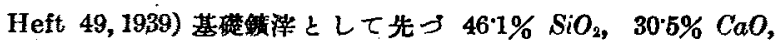

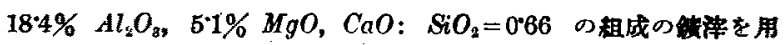

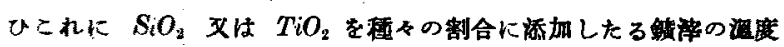

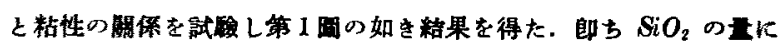

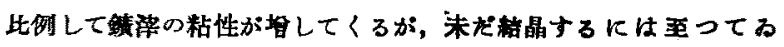

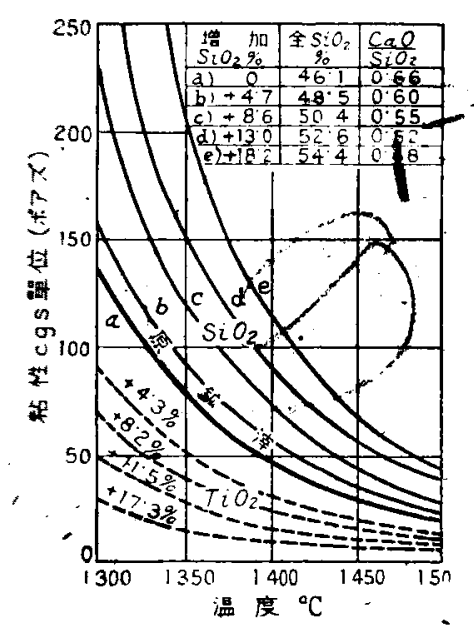

第 1 回 $30^{\circ} 5 \mathrm{CaO}, 46^{\circ} 1 \mathrm{SiO}_{2}, 18^{\circ} 4 \mathrm{Al}_{2}$

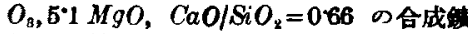
粘性火及海士 $\mathrm{SiO}_{2}$ 及 $\mathrm{TiO}_{2}$ の影 策 (白金中湘定)

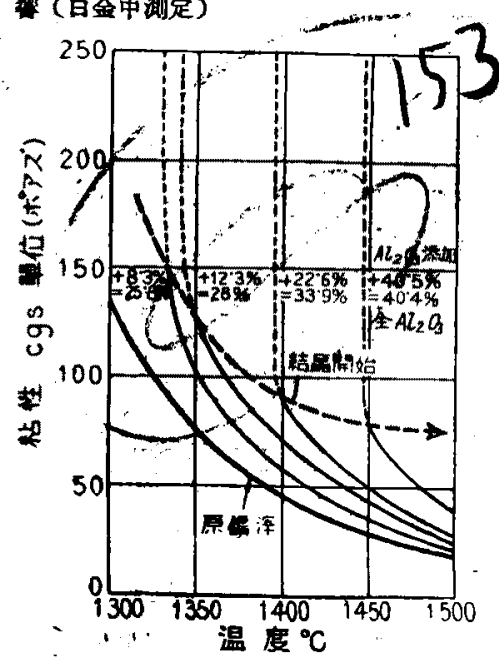

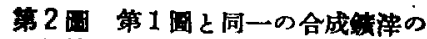
粘性に及汪す $\mathrm{Al}_{2} \mathrm{O}_{8}$ の影箱 (白 金中椡定）
ない. $1400^{\circ} \mathrm{C}$ で隹加

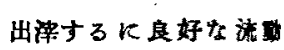
7 性としては少くとも75 ボフス゚以上を必要をす

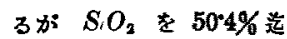
高めた場合即与 $\mathrm{CaO}$ : $\mathrm{SiO}_{2}=0.55$ での隻保

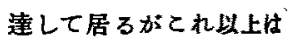
他の粘性走下げるいかが 加はら如り流㔍性小で ある。

TiO.

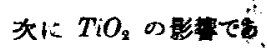
るが Fimmerbach 氏it $\mathrm{Ti}_{\mathrm{O}} \mathrm{O}_{2}$ 加㙁加厅る程粘栍

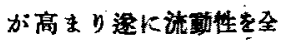
く失ってていぶので ろと稱して居るし同憡か 㮒驗を来国儿於て含和

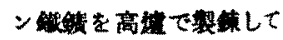
得て居るが A.J. R 氏はこれと反對下 $\mathrm{TO}_{0}$

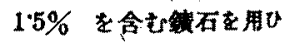
$2 \sim 25 \% \mathrm{TiO}_{3}$ の楼神

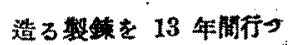

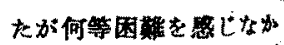

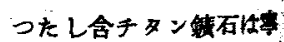

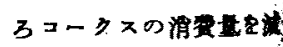

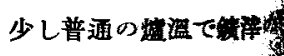
流動性は極めて良好なる ஆのであると程して庴 3. 又 F. Hartmann t:

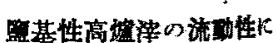




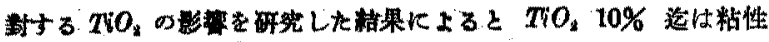

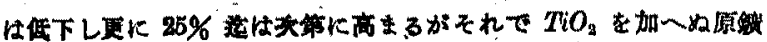

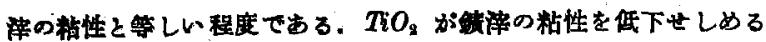

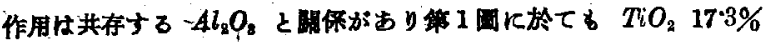
这枮性が头策们低下してるる。

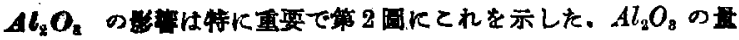

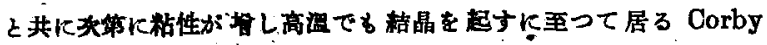

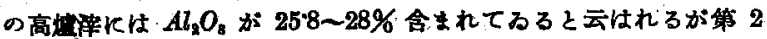

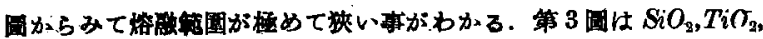

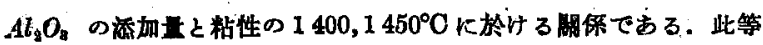

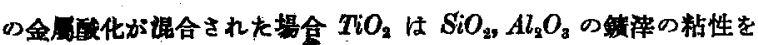

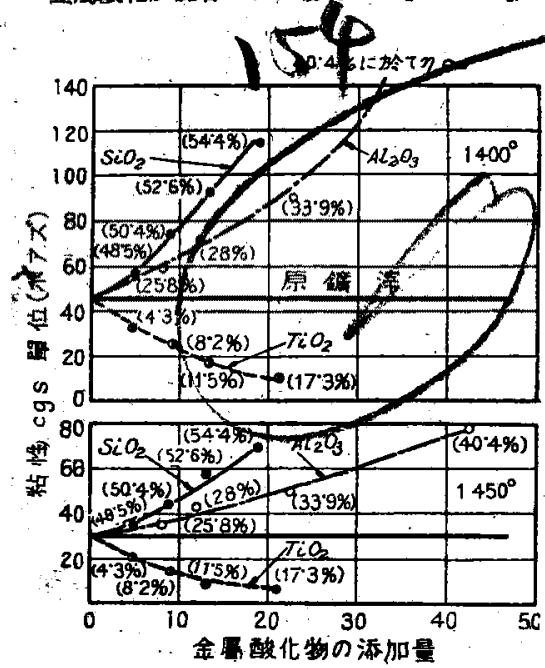

第3回 第1圆之同一合成鉬漳の粘性に

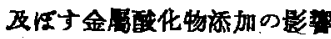

一何作用走打消 す役目をして居り $\mathrm{TiO}_{2}$ \& $\mathrm{FeO}, \mathrm{CaO}$, $\mathrm{MgO}$ アルカり等 飞数似の作用郎古 蚾㳯の数性を低下

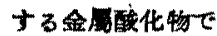
あることとなる。

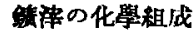
さり酭性及び筒基 性缕の粘性を K. Endell. R. Kley it $\mathrm{CaO}+$ $\mathrm{MgO}+\mathrm{FeO}+\mathrm{MnO}$ $+>n カ y+$ 硫 化物/ $/ \mathrm{SiO}_{2}+\mathrm{Al}_{2} \mathrm{O}_{8}$ $=\mathrm{Kz} \infty$ 值 $力 \times$ 占求 めて居万仿本研究

Кより TiO，粘性を低下せしめる元菜として考へられるから此等

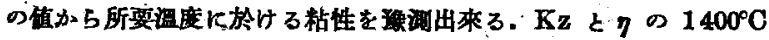

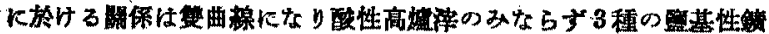

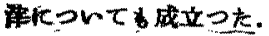

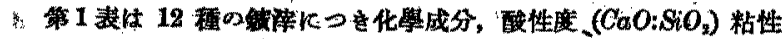

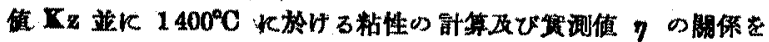

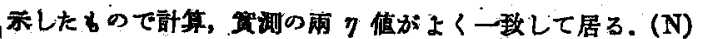

\section{H.}

(Renntnfelt 及び Kalling, Stahl und Eisen, Sept. 28, 1939,
Vol.59 No. 39, p. 1077〜1082) 特殊の制銅服原料々して直要なる

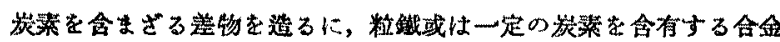
加ら乾式法に依り製造するととは 1936 年に創められ，以後多くの 瑞典の工場に於て作業研究が行はれ贸施可能であることが明かとな Dk.

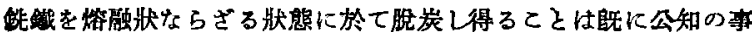

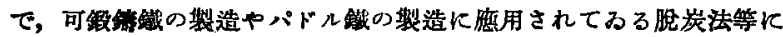
見ろ處である、例一ば P. Tunner が 19 世紀の中菜行行った銅の

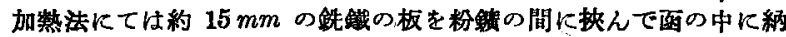

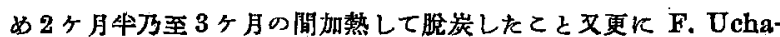

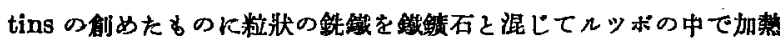

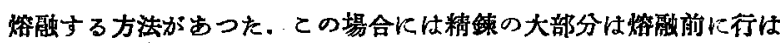
れたのでちる.

こ〉に著者等が迅速 Rennenfelt-Kalling 法々呼占乾式法は前

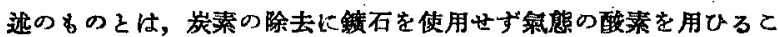

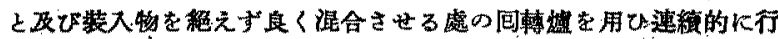
蓑點を異にしエるる。

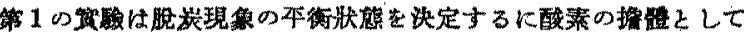

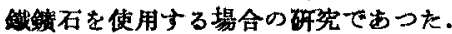

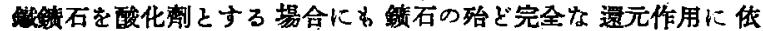

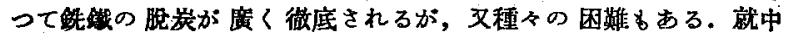

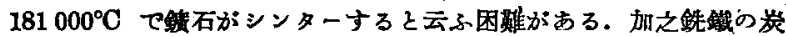

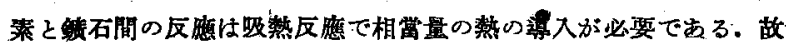
に後には酸化劑として $\mathrm{CO}-\mathrm{CO}_{2}$ の湜合肪入を炭素のみが酸化され

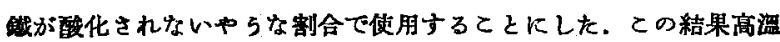
庨を使用することになり，反應は促進され且完全となった，又との ガスの反應熱を利用し得る故に，反锶は吸熱性であるが反應は促通 され作業の遂行は大い认施單となった.（原交第 1,2 圖の平街狀能 圆火依つて $\mathrm{CO}-\mathrm{CO}_{2}$ 混合ガスの $1 \mathrm{~atm}$ 下於ける銧践の脱炭の程 度が示されてるる．邓ての線圆には前記の方法の根柢をなす 3 つの 化學繁化が示されてるる。

$$
\begin{aligned}
& \mathrm{FeO}+\mathrm{CO} \rightleftarrows \mathrm{Fe}+\mathrm{CO}_{2} \\
& 2 \mathrm{CO} \rightleftarrows \mathrm{C+CO} \\
& 2 \mathrm{CO}+3 \mathrm{Fe} \rightleftarrows \mathrm{Fe}_{\mathrm{n}} \mathrm{C}+\mathrm{CO}_{3}
\end{aligned}
$$

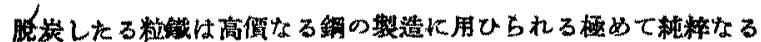
原料である、就中，序鐵の有つ公知の缺點を有せざる點で匴れてか 3 .

\begin{tabular}{|c|c|c|c|c|c|c|c|c|c|c|c|c|}
\hline \multirow{2}{*}{ No } & \multicolumn{6}{|c|}{ 化 學 成 分 \% } & \multirow{2}{*}{$\begin{array}{l}3 \pi \\
\Rightarrow y\end{array}$} & \multirow{2}{*}{$\begin{array}{c}\mathrm{CaO} \\
\mathrm{SiO}_{2}\end{array}$} & \multirow{2}{*}{$\mathbf{K} \mathbf{z}$} & \multicolumn{2}{|c|}{ 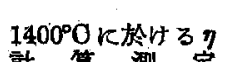 } & 製法的如き製鋼法に使用 \\
\hline & $\mathrm{CaO}$ & $\mathrm{SiO}_{2}$ & $A l_{8} O_{8}$ & $\mathrm{MgO}^{\circ}$ & $\mathrm{FeO}$ & $\overline{M n O}$ & & & & 計 3 & 测 定 & れば更に一屡均等なる熔解 \\
\hline 1 & $18: 6$ & $47 \cdot 3$ & 188 & $=7 \times 6$ & $2 \cdot 7$ & $\div$ & $46^{-}$ & 0.39 & 0.51 & 83 & 83 & \\
\hline 2 & $17 \cdot 5$ & $46: 3$ & $18^{\circ} 4$ & 48 & $7: 5$ & $2 \cdot 1$ & 2.8 & 0.38 & 0.54 & 55. & 60 & • 又整基 \\
\hline 3 & $18 * 2$ & $48: 3$ & $107^{\circ}$ & 33 & $7 \cdot 7$ & 27 & $2 \cdot 2$ & 0.38 & 0.58 & 38 & 43 & 法及び監基性䉓氣爈法に於 \\
\hline 4 & 268 & $48 * 8$ & $17 * 2$ & 46 & $3 \cdot 3$ & 0.4 & $2 \cdot 3$ & 0.59 & 0.59 & 35 & 41 & ても有利炕使用される。殊 \\
\hline$\dot{5}$ & 29.4 & 430 & $170^{-}$ & 45 & 19 & $0 * 6$ & $3 \cdot 1$ & 0.69 & 0.66 & 23 . & 24 & と特珠の性質を有する鋼の \\
\hline 6 & $30 \%$ & 412 & $18 \cdot 5$ & $4 \cdot 1$ & 25 & 10 & $2 \cdot 2$ & 0.73 & 0.67 & 22 & 23 & \\
\hline 7 & $34: 5$ & $39 \cdot 2$ & $13 \cdot 1$ & 46 & 39 & $2 \cdot 1$ & 17 & $0 \cdot 88$ & 0.90 & 11. & 11 & \\
\hline 8 & 305 & $40^{\circ} 1$ & $18 \cdot 4$ & $5 \cdot 1$ & 一 & 一 & - & 0.66 & 0.55 & $49^{\circ}$ & 48 & の方法は他の製銅法々租合 \\
\hline 9 & 310 & 414 & $16 * 6$ & 30 & $2 \cdot 0$ & 17 & $S=1$ & 075 & 0.66 & 23 & 23 & 世て行ふとと加出來る. \\
\hline 10. & 398 & 347 & $8 * 5$ & $9.8^{15}$ & $2 * 0$ & $7 \cdot 5^{12}$ & $\mathbf{S}=\mathbf{3}$ & $1.0^{12}$ & $1 * 3$ & 55 & 35 & 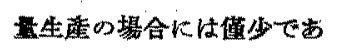 \\
\hline 11 & 461 & 333 & 82 & 54 & $1 \cdot 1$ & $2 \cdot 3$ & $s=1 \cdot 4$ & 14 & $1 \cdot 4$ & $5 * 5$ & $4 \cdot 5$ & 3.との方法比於ては烧鉿 \\
\hline 12 & 410 & 318. & 157 & 46 & 18 & 048 & $s=0^{*} 7$ & $1 \% 3$ & 100 & 9 & 7 & 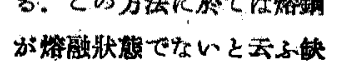 \\
\hline
\end{tabular}

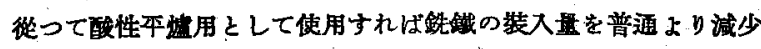

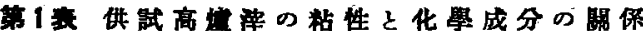

さるととが出來る。.邓他の 几ッボ更び酸性の高周波螘

\section{西}




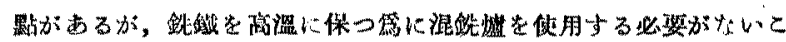
とで或る程度情ふととが出來る。

第一に轉媪製鍊を用ひる二段制銅法と比較すればこの $\mathrm{R} \cdot \mathrm{K}$ 法

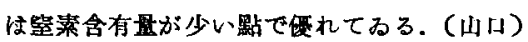

\section{5. 鐵及び鋼の鋀造}

\section{Randupson 法 (セメント型法)}

(Parker, W.: Found. Tr. J., Mar. 20, 1941, p. 194) ランダプ

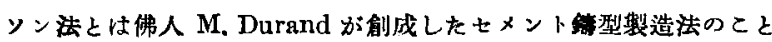
で主として佛國の Ugineの Société de l'Electro-Chimie et de l'Electro-Métallurgie et. des Acièries Electriques d'Ugine $て$

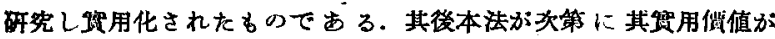
認められ現在では佛，英，米，城，伊等の諸國で，こ」数年來旺 んに探用されるに至つたるのであるが抑々中子砂にたメントを混じ て用ひる束の應用性が喝一られたのは既に1897 年であってセメン

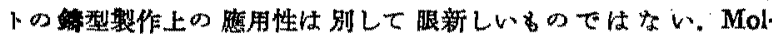

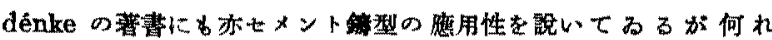

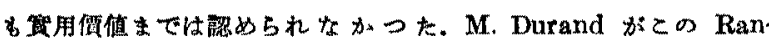
dupson 法を創案し筫用化してから始めてセメント错型製作法が大 成したと云ってい過言ではないゃらである。本法は普通の製型法と は可成異つてるて單にセメントを型砂に混合する丈の方法ではな

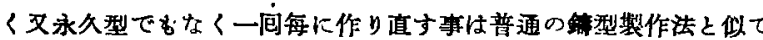

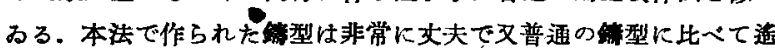
が通氣性が良い，又䤡型の强度が强いために锖枠を要しない，例

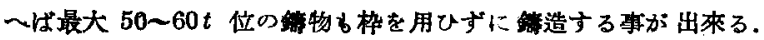

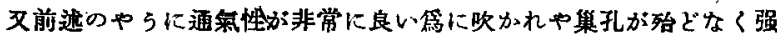
度のつよいために掬はれ之か押し达みのや5な製型不俌から來る缺 陷る殆じないのは非常な利點である。一方型の收樎の點は普通と大

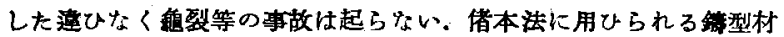

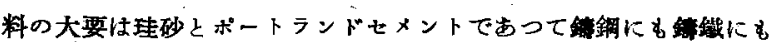

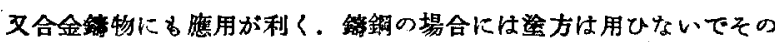

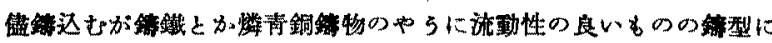

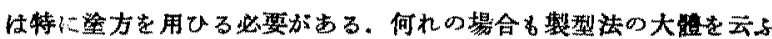

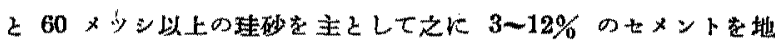
金や品物の種数に上り混して更に丁度硬化に必裂な程度の水を混し て調砂し製型するのである：その製型に當っては普通の方法と大盖 なく，主型や中子の場合普通のやらにつき作らてめるが大物の場合 には铱棒丈を芯金として砂中に埋め及，高り環等す埋める．大抵の 場合木製の枠を用ひて仕事をする，边め終うたるのは枠を天地して

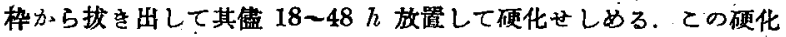

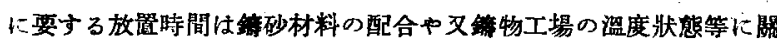
保してきるるのである。少くとも $45^{\circ} \mathrm{F}$ の氛温さへあれば大き な型でる $48 h$ 以上放蹎する必要はなく $36 h$ で鋅鋼の埸合です十

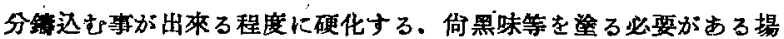
合には更儿數時間それが畭燥する篇儿放置する必要があるが，むし ガス・バーナー等であぶれば數分間で浐む事になる，4 尺角迄の鍑 型なら木製定盤の上飞のせて硬化せしめるか其以上の大物では数形 を防ぐ篇に鎆板製定盤を用ひる。硬化が完了したら型き適當に楴め

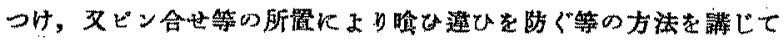

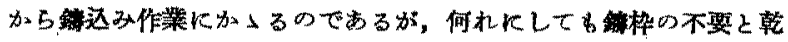

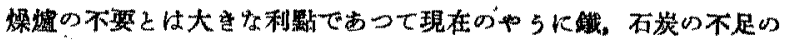

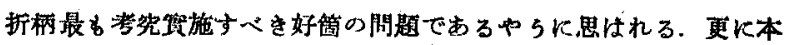

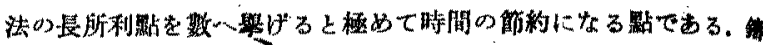

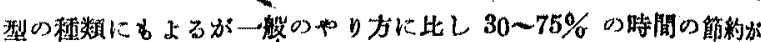

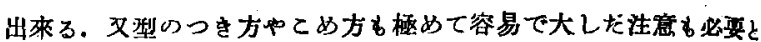

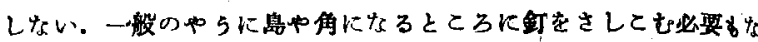

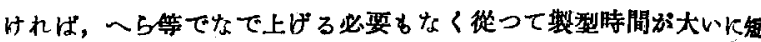

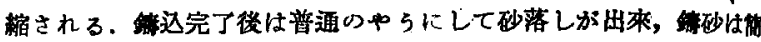

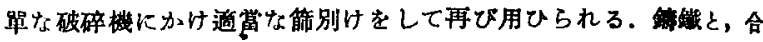

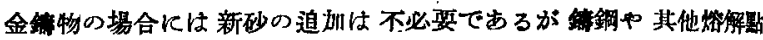
の高い金風の場合には肌砂丈は新砂の配合したるのを用ひる.此

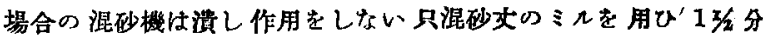
位の混砂で十分である：佾念ざの仕事の場合には乾燥湕に入れて

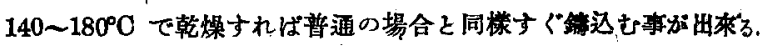
偖以上で本法の利點丈を述へたが缺點についてる 茺へる必要があ，

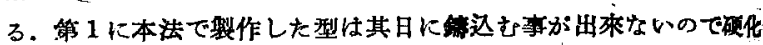

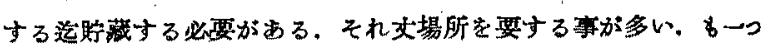

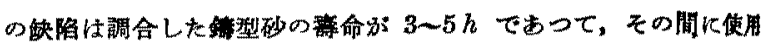

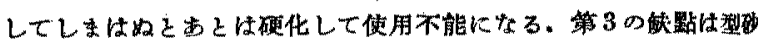

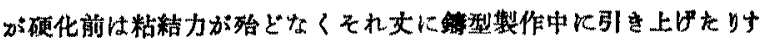

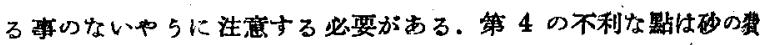
用が高いと云小點である. 尤も此點は本法の幾多の利點加ら考へる

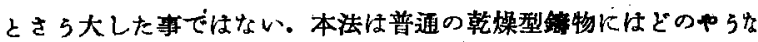

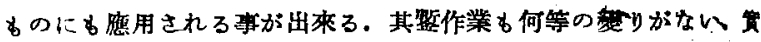

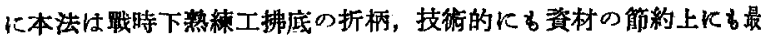

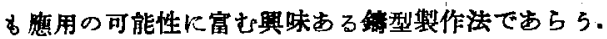

(网藤)

\section{6. 鐵及び龬の加工}

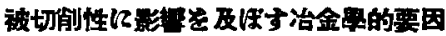

(Metal Progress 36 (1939) p. 53-6)銅の被切制性飞影慗を及

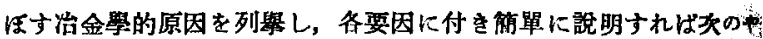
亏以なる。

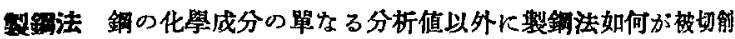

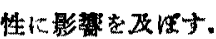

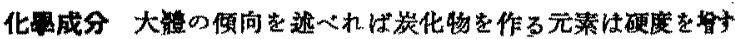

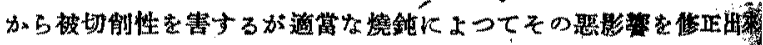

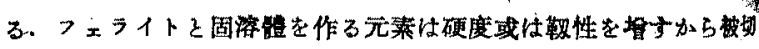

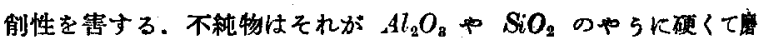

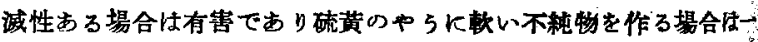
般に有利である。

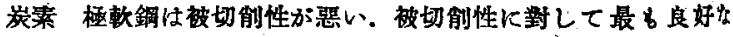

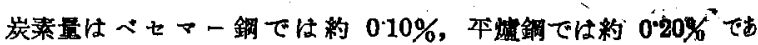
3 .

エンガン $M n$ の影警は $C, M n, P$ 等の全含有量如何に上る。普

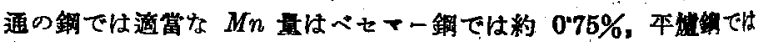
䄪 $1.00 \%$ である。

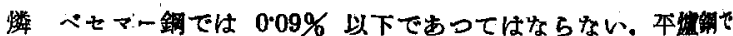
は約 $1.0 \%$ まで $P$ を加へる之被切制性加や小良好になる。

硫䜤 $S$ は被切剈性を良くする篇火最る普通火使はれる。する 高限度までは $S$ を增せば好結果を得るが、最滈限度がど程度て

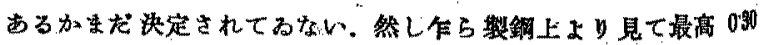
\%までされてるる。

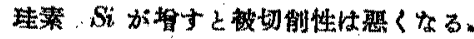

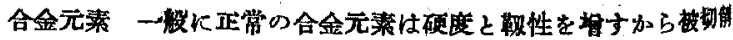




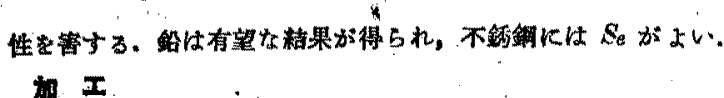

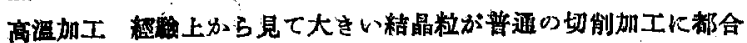

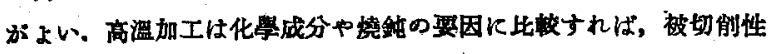
にみ住す影管が少いと思はれる。

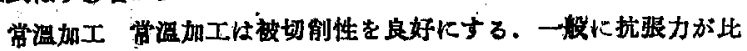

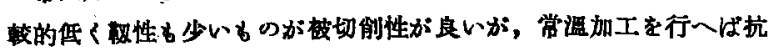

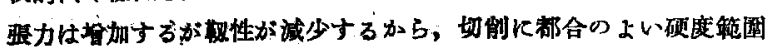
187 217 HB を越えない程度に硬化されるならば常盢加工により 被切削性加良くなる。

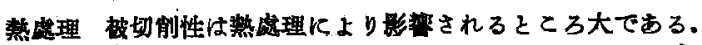

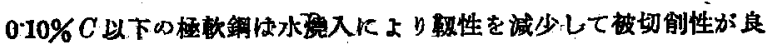

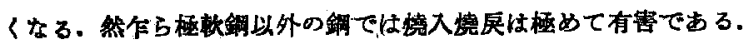

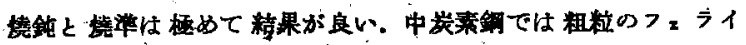

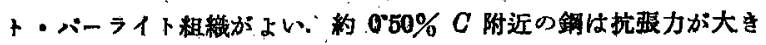

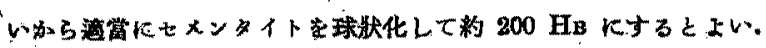

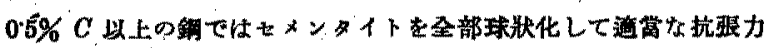

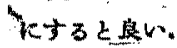

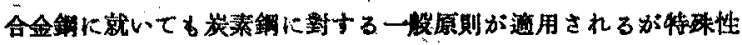

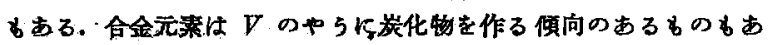

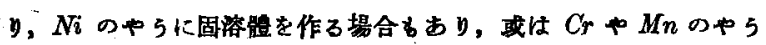

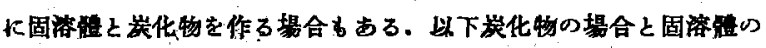
堨合炏分けて远へる。

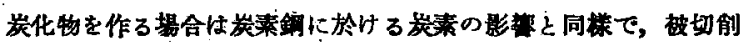
珄を良好にする熱處理は大して困嚾ではない。

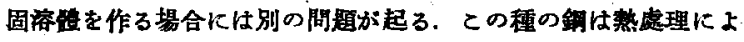

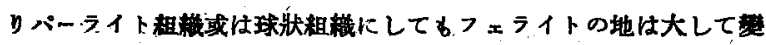

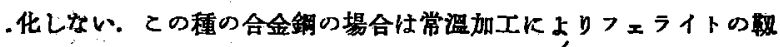

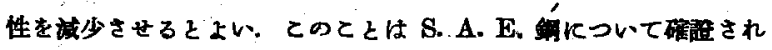
てるる。

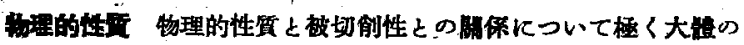

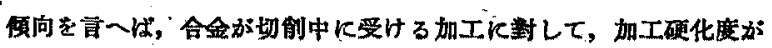

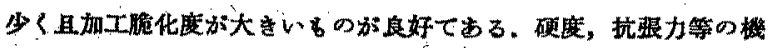

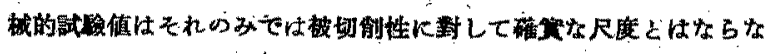
w.

(\# 手)

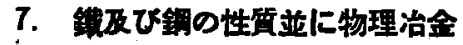

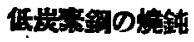

(Wallace Rickett: Trane. A. S. M. 28 (1940) 333-353) 種

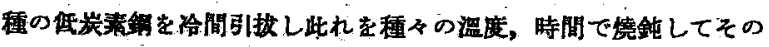

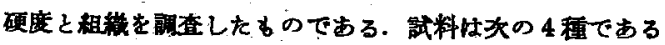

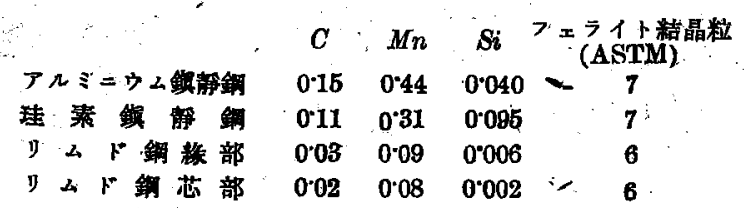

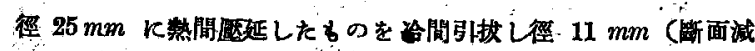

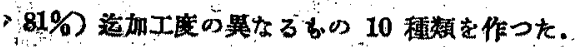

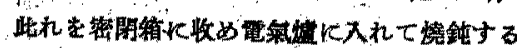

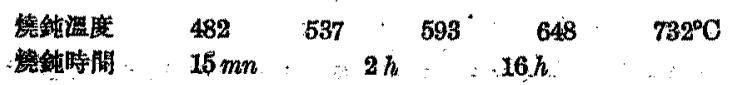

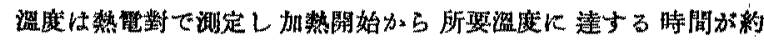

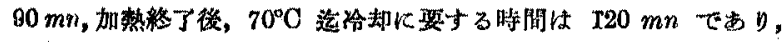

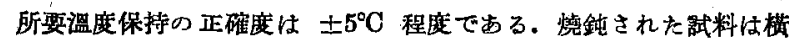

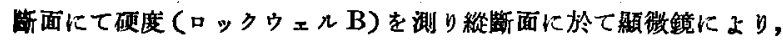
結晶粒の㤘化を铜查した。

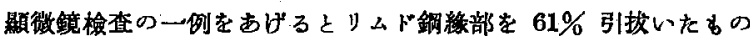

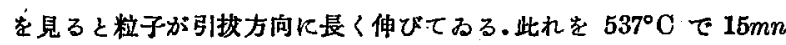
蛙鈍すると結晶粒界儿新結晶加發生してるるのが見られる.更に $16 h$ 燒鈍したるいを見るとフェライト粒子が完全に再結晶をして るろ. 引城の影警が租織に市らはれるの加工度加 $30 \%$ 以上のる ので, 18\% 以下の低加工のるのに於ては燒鈍に際して,粒界に新粒 子の發生を見ないで長時間高温で加熱すれば元の粒子がその儘成長 し，著しく大きな粒子になつてしまふ。此れを粒子の過成長といふ 事にする.

アルミニウム船静鎙等では多少パーライト粗織を含んでるるが此

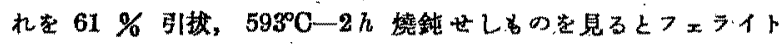

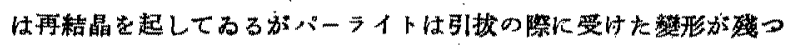
て居り一部球狀化が起つてるるのが胃られる。同じすのを $648^{\circ} \mathrm{O}-$ $16 h$ 烧鈍すると，フェライトはずつと粗大炕なりパーライトは完

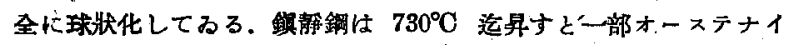
トKなるから跲却にあたつて再びパーライトを生ずる.リムド鋏で は炭化物は粒桀になってるるが $730^{\circ} \mathrm{C}$ に热すると, 一且溶解し冷 却するを結晶柆界に不规則な形狀で析出する。

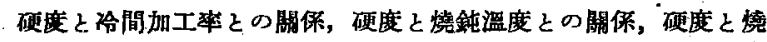

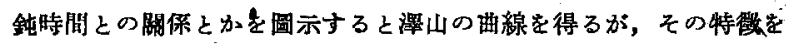
拾つて示すと次の第 1, 第 3 圆の如くなる.

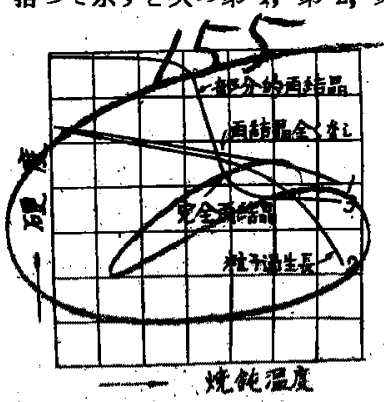

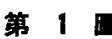
筆工國ほ结鈍㴓度が硬度及び結晶

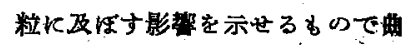
楾 1 は祫間加工卒中燒鈍時間方比 較的少く，高盜に於て嬈鈍して

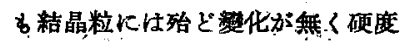
が僅为減少するだけである。曲 線 2 は曲線!上り冾間加工る大

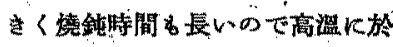
て著しい軟化を起し非常に粗大な フェライト粒子が成生する. 曲線

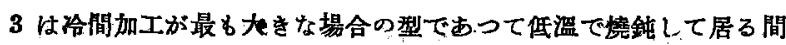

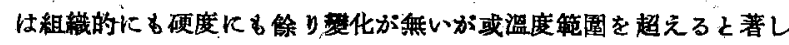
い软化と再結晶爻は粒子生長を起す．更に高㴧にすると粒子の生長

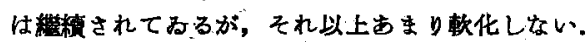

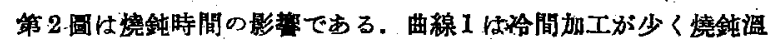

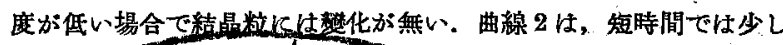

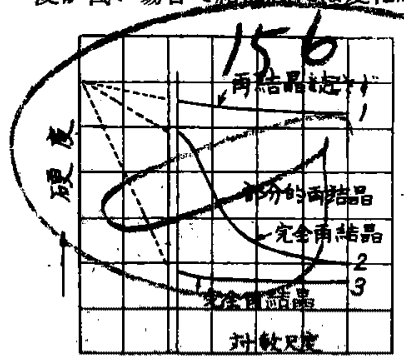

始化温度

萧 2

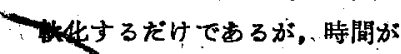

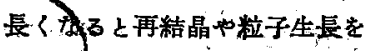

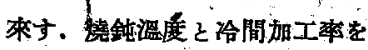
或る租合にした時に此のゃらな 整化走示与：曲線 3 は冾間加工 が大きく烧鈍温度加高いので直 飞软化示示場合で告る。㭙間 它長くするとフェフイト粒子は

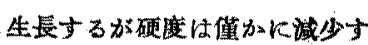
$\therefore$ るだけである。 


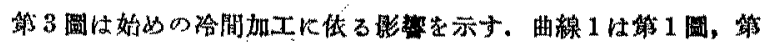

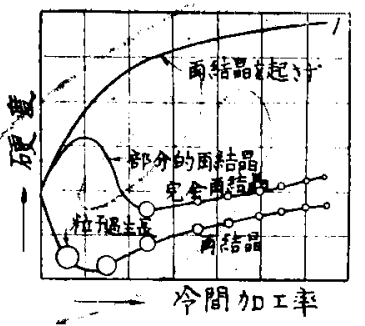

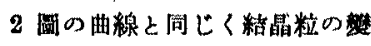
化はない，從つて冷间加工の著 しいるの程便くなつてるる。曲 線 2 惊冾間加工策が或る値にな つを所で部分的再結晶を起し， 冾閒加工がすつと大を少所では 完全に再結晶してるる. 完全に 再結奛せる笵团では糸形量が大 第 3 圆 主い程硬庭が大で結晶粒が小さ

い. 曲線 3 に於ては冷間加工柪が注んの僅かであつてす粗大なつエ ライト粒子を生じ硬度は最小である。加工本がより大きくなると硬 度は大すくなり粒子は細为くなる。

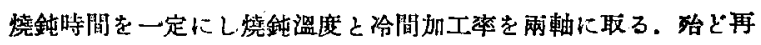
䊅晶を示さず硬度が僅加に減少して，所請「四復」の現象を示す あのをので, 部分的再粘晶を示せるるのをので，完全と再赫晶せる

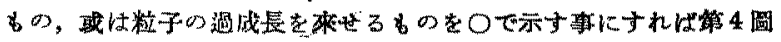

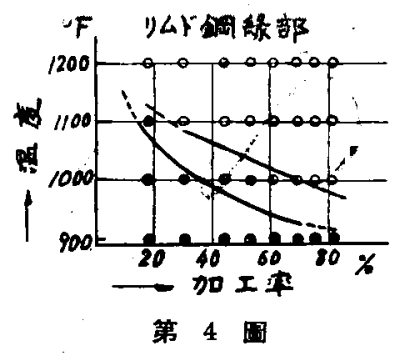

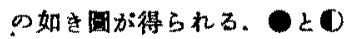
の間に引いた曲線は践料が部 分的再結品を起すゃらな條件 を示するのであり，问样にの と○の間の破線は, 再結晶が 完全になるか粒子の過成長を 起す條件老示するのである。 てのや5な踢を各鋼種儿就て 描きこの破線のみを一枚の圆

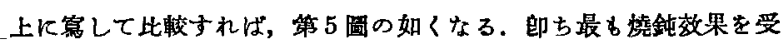

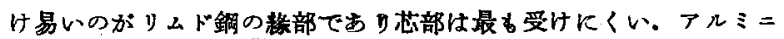

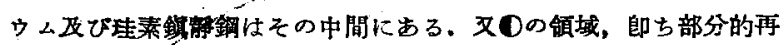

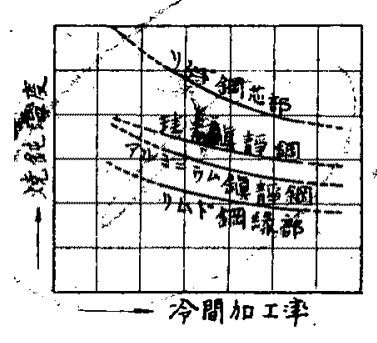

第 5 阅 結晶を起せる範图も亦りムド䜌部 は最る部く，芯部最す成くて，

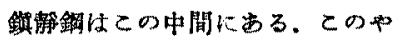

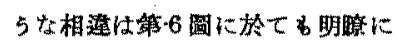
あらはれてるる.或加工辈の所で は移部が完全に再粘晶してるるの К，芯部ば会く敏化が無く硬度に 著しい差がある。このやらに著し

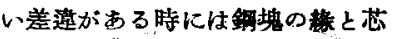
ら間に非常にはつきりしを境界線が見られる。アアミミウム鎮静钢

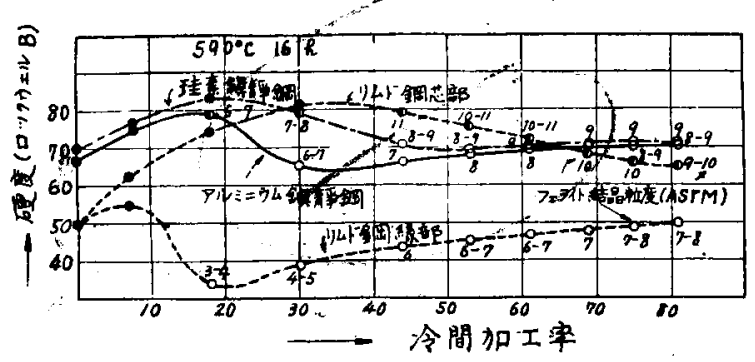

第 6 圆

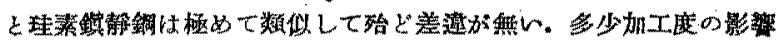

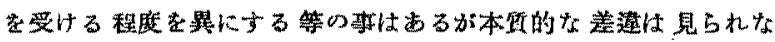
, (安 田)

\section{軸坌用 理}

(Morton, H. T.: Metal Progress, Feb., 1839: p. 149) 著者

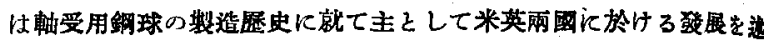

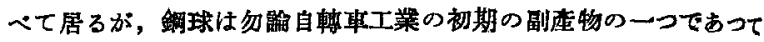
英人 Wm. Brown が 1880 年に最初に軸受銅球を慗造したのであ

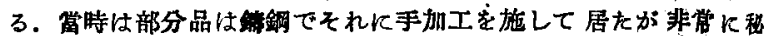

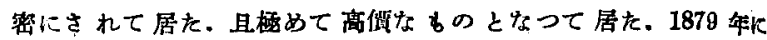

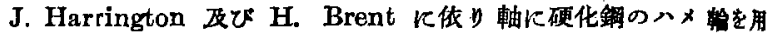
ひる特部が出で，之れは軸受鎆球用の清にる應用せられたが，その 挠W，Hillman は銅線より銅球をつくる機械を設計した。 この

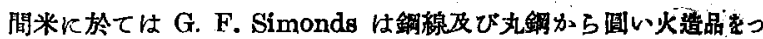
くろ機械をつくり鋼球を製造した，摆息では 1890 年頃に Clevela nd Screw Machine Co. $\perp y$ Dentsche Waffen und Muri.

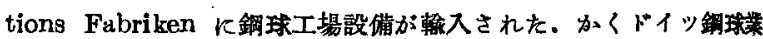
はその㓣業に於てアメリカの發明に依つて居り，上迅の會社は此の

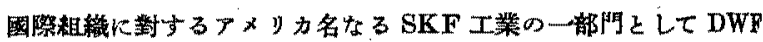
なる㒀標索用ひて居る。

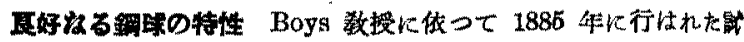

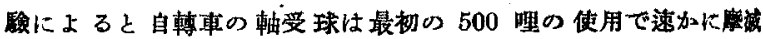

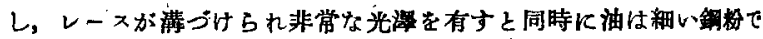

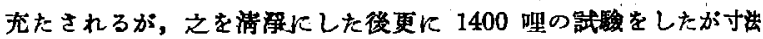

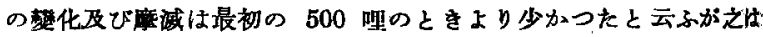

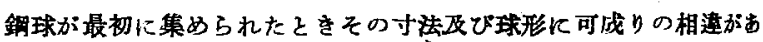

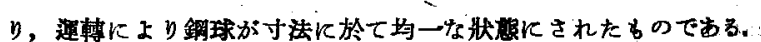
鈵球製造に於て自動機械の使用は球の性質及び均一性を著しく㳊 良し他工業では䦎かれない公差に達した。19 世紀中には銅球製造

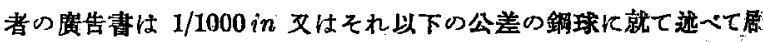
3. 1907 年に Henry Hess は機械技街者アメリカ坫會の刺告に

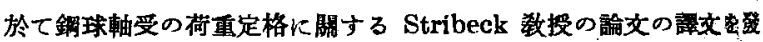
表し，同時に製造及び使用の楑酸より尊い自身の論評を远へて居

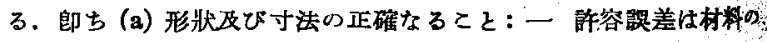

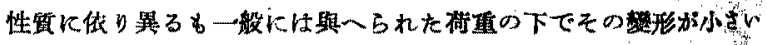

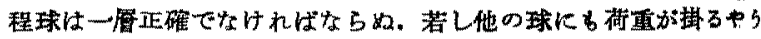

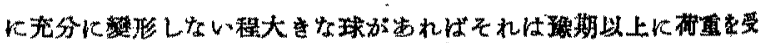

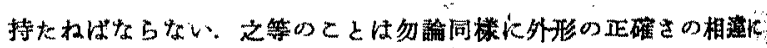

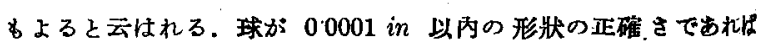
すへての要求は充される：(b) 高度の表面仕上が必要なるてと：一

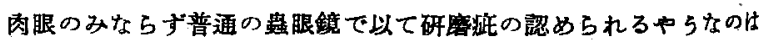

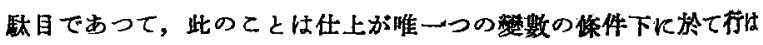

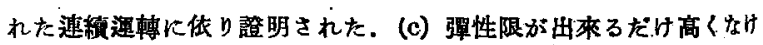
ればならない（d）硬度及びその均一性は球全體を通じて最高度ま で必要とされる.（e）正確な知識と均一性とは彈性限及び硬度ら䒺 求よりる一層重要である。

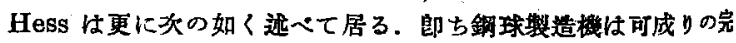
全さに達して居るが寸法に於て 0.0001 in の制限內の球件の性

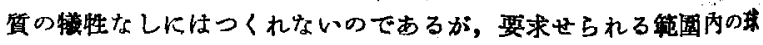
を選辈して等級をつけるととは可能なととである。

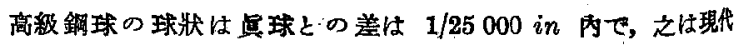

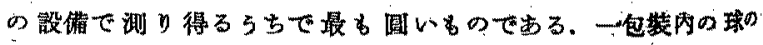

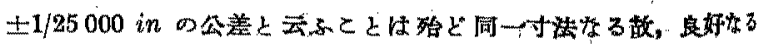

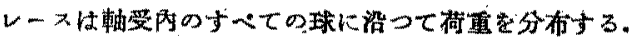

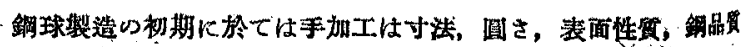




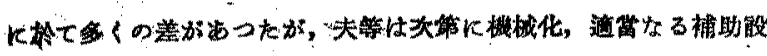

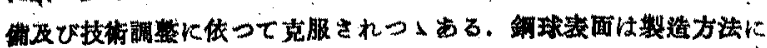

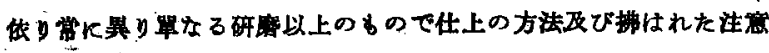
下传万.

1907 年黄㭙の 製造法は成形して乾式研磨機で 粗仕上げし，䃌

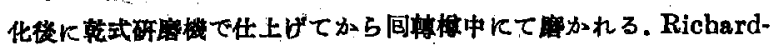

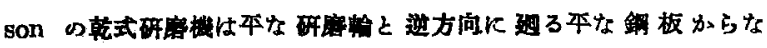

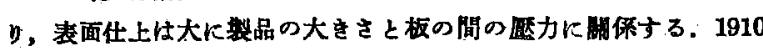

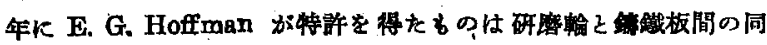

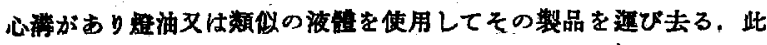

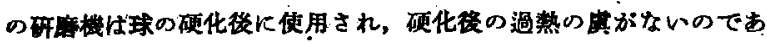
3.

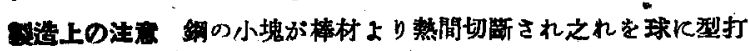
して磭りを切り取る(小さな球即ち $1 / 2$ in.徨程度のちのでは機

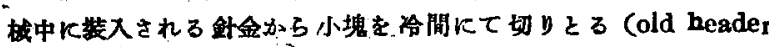

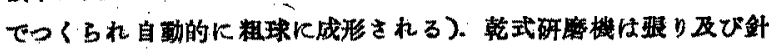

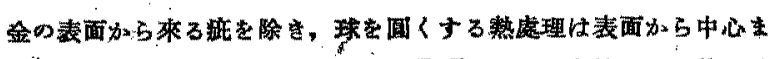

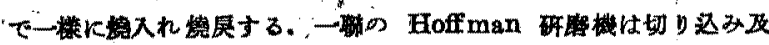

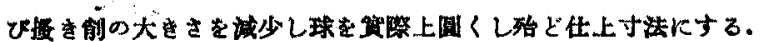
石灰中での轉しは前の研唐に上る“け代”它除く一方仕上の皮研

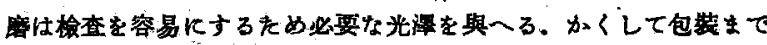

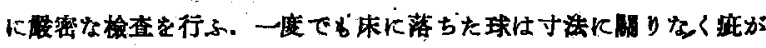

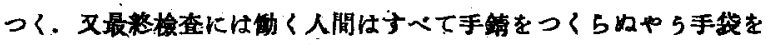
はめる.

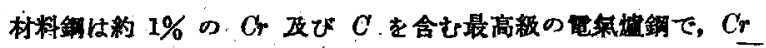

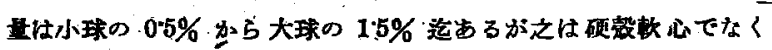

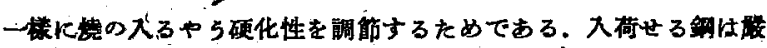

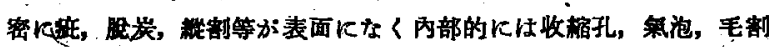

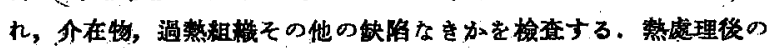

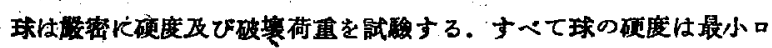
シクウェス060であらねばならか.

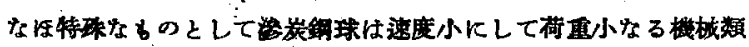

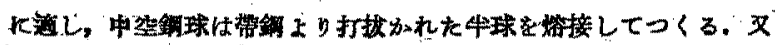

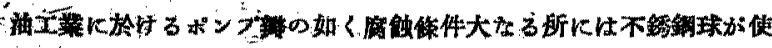

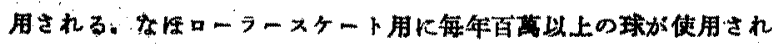
て居了。

(戥䗁)

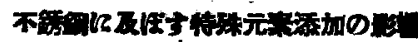

Franks, R. Trans, A. S. M. 27 (1939) 505 -520) 㧿來不銹

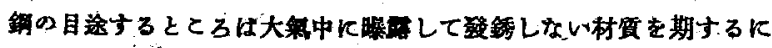
在つ $\tau$, Brearley

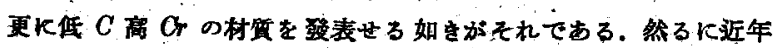

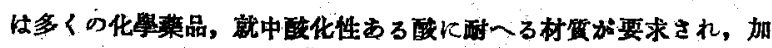

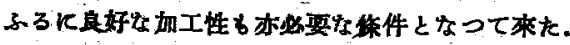

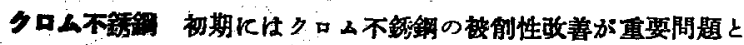

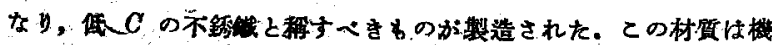

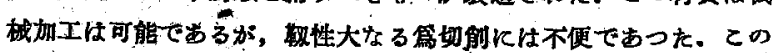

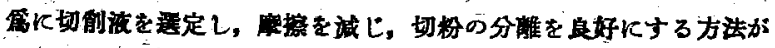

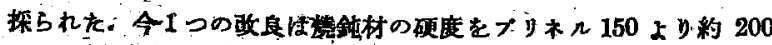

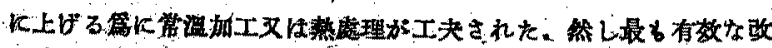

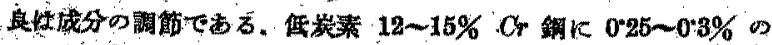

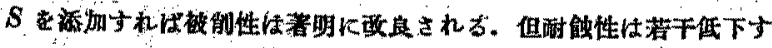

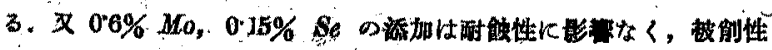

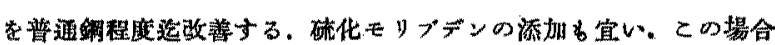
は $<0.65 \%, M o, 0.40 \% \mathrm{~S}$ 之名る。

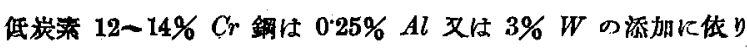
政善される，Al は自硬性の低娍，W $W$ 强鞄性の附與加目的であ

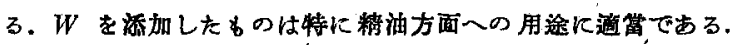

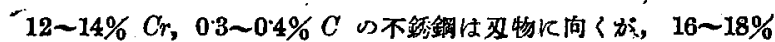

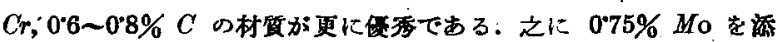

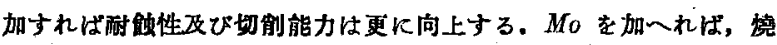
入溫度を $950^{\circ} \mathrm{C}$ より $1000^{\circ} \mathrm{C}$ に上げるととが必要である。この铜 は高溫に長く保持すれば結晶粒の成長を來すから泩腺を要する。

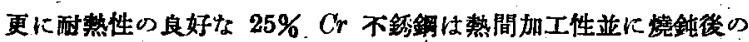

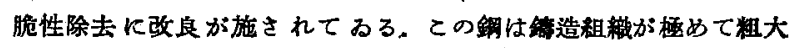
で，加工後燒鈍して脆性を示すのは著しい混粒組織に原因する。 $N$ をフェロクロムに含ませて添加すれば鉝塊の結晶粒を微細化す

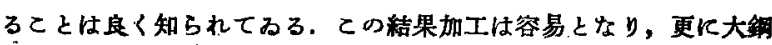

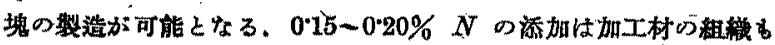

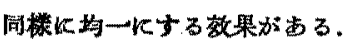

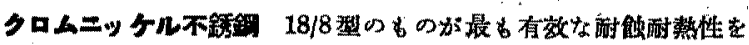

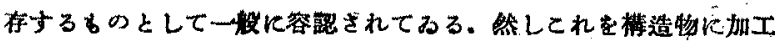

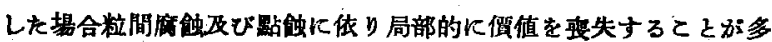

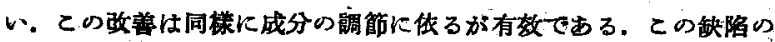
1 つはオーステナイトー分解であつて 300〜800年 K加熱すれば意

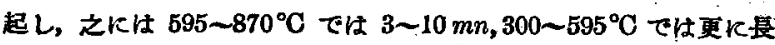

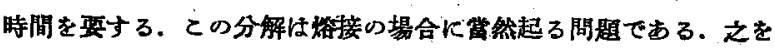
防止する篇の成分的䬰には $C$ が最る重要で，單に $C 007 \%$ 以 下低下することでは解决されない，最も有数なのは $C 8, T i$ 等の 涯加である.Ti の添加は $C$ 量の6 倍を要し，之を安定化する第 $850 \sim 900^{\circ} \mathrm{C}$ K 2 4 $h$ 加熱し空冾する必要がある. との處理をな

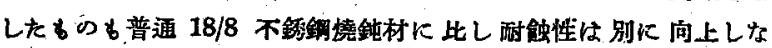

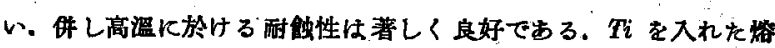

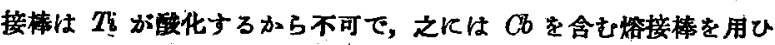

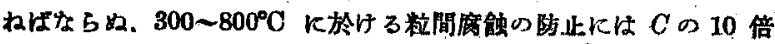

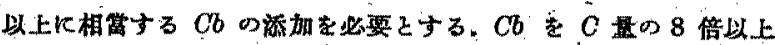

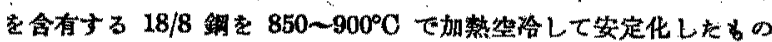

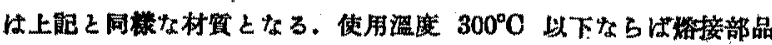

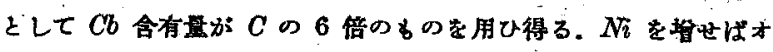
一ステナイト領城の咸くなるはよ知るとてるでする。

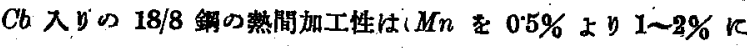
高めれば大となる. 又 $C b$ を含を 18/8 龬は蛒接棒として有效で，

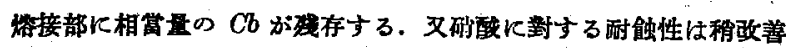
される. 炇接棒の硫黄量を 0.7\% 附近に一定するととは $C b$ の步留

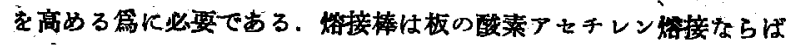
17.84 $\mathrm{Cr}, 974 \mathrm{Ni}, 1 \cdot 16 \mathrm{Mn}, 0.41 \mathrm{Si}, 0.08 \mathrm{C}, 0.85 \% \mathrm{Cb}$ が宜

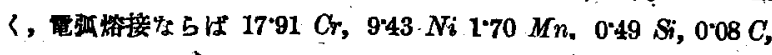

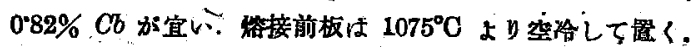

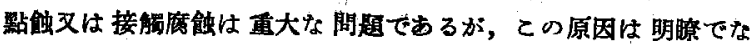

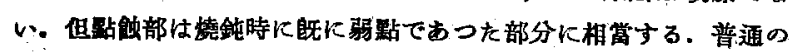
介在物中炭化物は重要な原因ではない。との試黪には pH 7〜4の

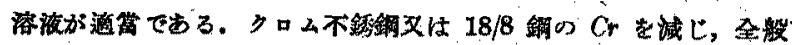

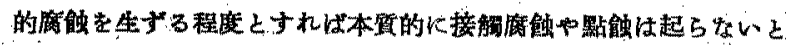

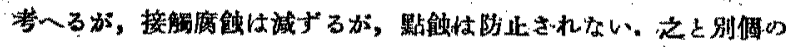

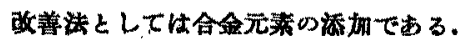




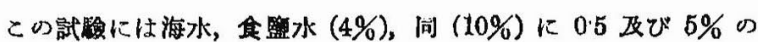

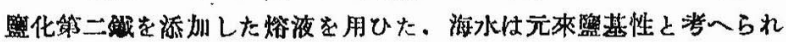

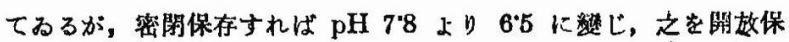

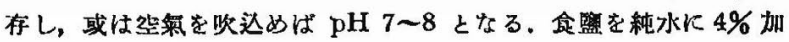

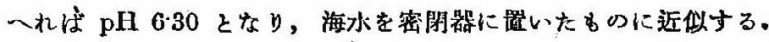
この溶液は長時間の點蝕欲驗に便利であるてとが制つた。稙々の元 素を添加した $\mathrm{Cr}$ - $\mathrm{Ni}$ 銅を試驗しを結果では $2 \% \mathrm{Mo}$ を添加する ととが有效なりと認めた。.Mo より更に强力な炭化物形战元素を 加一れば更に優秀である。之には $\mathrm{Cb}$ と，Mo 併用するがょい。 $18 \mathrm{Cr}, 14 \mathrm{Ni},<0-1 \mathrm{C}, 2.5 \mathrm{Mo}, 0.5 \% \mathrm{Cb}$ のb のは相當酷な狀況

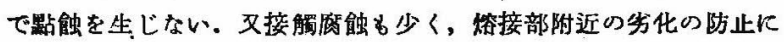
何等特别等處理を行はなくても宜い。

一 Si の添加耐酸化性を嘴すが結晶粒の成長を來し易い.Mnは 加工性, 汾接性等を改善し, オーステナイトを穻定化する。. 從つて $N i$ の一部を $M n$ で䁌換する心は有效である. Cu は或る場合耐蝕 性を高める. $W$ は高溫强度を大とし, $\mathrm{Co}, \mathrm{Mo}, \mathrm{V}$ 等汢高 $\mathrm{Cr}$ 鍋つ

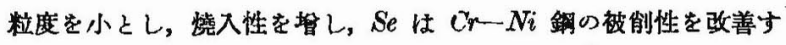
る数果がある。

(前 田)

\section{ニオピウムー鐡合金}

(R. Genders \& R. Narrison, J. Iron Steel Inst. 139 (1939 -II) $29-37$ p.) $N b-F e$ 系に閶して同著者の㵝交 (J. Iron Steel Inst. (1936) II, 173 p.) の外, 狄の 2 論交㒛め了. R. Vogel \& R. Ergang, Archiv 12 (1938) 155; H. Eggers \& W. Peterr, Mitt. K-W-I • 20 (1938) 199.

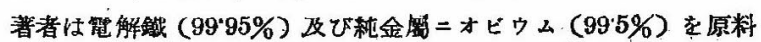

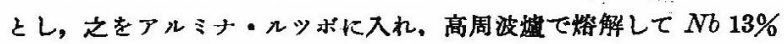

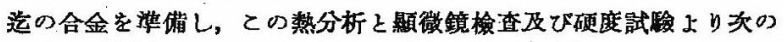
狀態圆を得た。

一般に Nb $50 \%$ 迄の会社 $\mathrm{Fe}-\mathrm{Fe}_{\mathrm{a}} \mathrm{N} b_{\mathrm{a}}$ 系として报ひ得る。

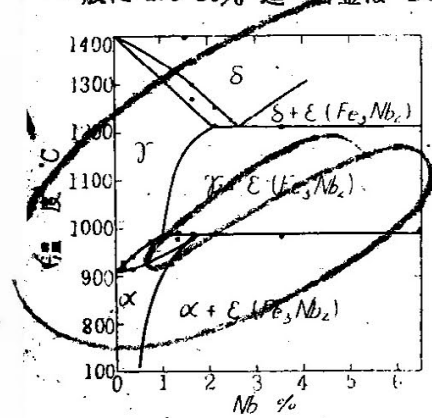

第 7 橉 とひ $\mathrm{Fe}_{3} \mathrm{Nb}_{3}(\varepsilon)$ と $\delta$ とい 共晶點は $N b 18 \%$ を有する。 $\mathrm{Fe}_{3} \mathrm{Nb}_{2}$ の $\propto$ 一の溶解度は 常温で極めて少く, 㮖かに $0.36 \%$ であるが, $989^{\circ} \mathrm{C}$ の 包析溫度では $18 \%$ となる。 $\gamma$ 一の溶解度 \&同漛飞增加 L, $989^{\circ} \mathrm{C}$ で $1 \%, 1220^{\circ} \mathrm{C}$ の共析溫度で $2 \%$ となる。 $\mathrm{Fe}$ に $N b$ を添加すれば, 硬度を暂加する。現在 $\mathrm{Fe}$ 一

$N b$ 純合金は工業的用途は見出し難いが，㧘化銅に用ひれば $T a$ 以 上の效果加期待される.

(前田)

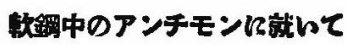

(Tones, B. \& J. Morgan: J. of Iron \& Steel. Inst. 1939-II)

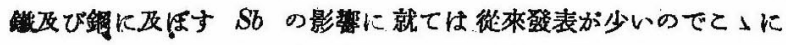

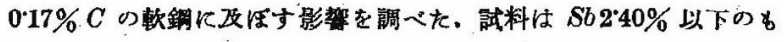

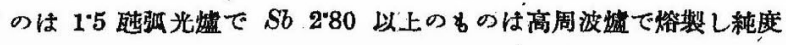

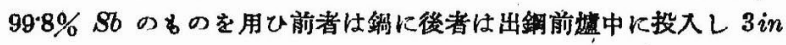
$\phi \times 18$ in の銅塊化鎍造した. Sb の步留は比較的良好である. 試料 の成分は前者苦 $0.15 \sim 0.18 . C, 0.29 \sim 0.34$ Si, 0.62 0.70 Mn,0.028 0*041 S, 0*027 0*044 $P, 0 * 30 \sim 034 C u, 0 \sim 2 * 40 S b$. 後者は 0.03 $\sim 0^{\circ} 24,0^{\circ} 07 \sim 0^{\circ} 28$ Si, 0.15 0.56 Mn, $0^{\circ} 030 \sim 0^{\circ} 035 \mathrm{~S}, 0^{\circ} 036 \sim 0^{\circ} 042$
$P, 0027 \sim 0 * 30 \mathrm{Cu}, 2 \cdot 80 \sim 19^{\circ} 00 \mathrm{Sb}$ である. 鋼塊のパイプは

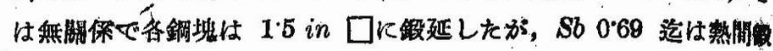

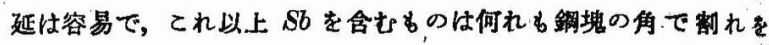

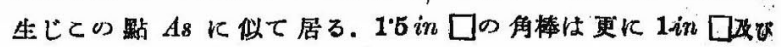

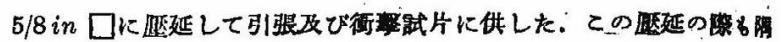

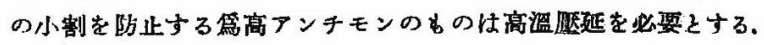
鋼中の $S b$ の分析は純粹の硫化アンチモンを分離して顛素カリウム の標瑯液で滴定する法が良い。

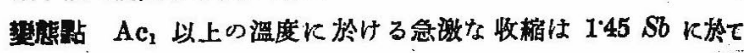
消失し $S b$ は $A c_{8}$ を高的 $0 \sim 280 S b$ で 860 940 $0^{\circ} \mathrm{C}$ 迄上算す

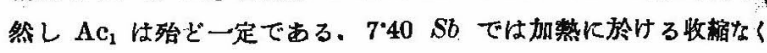

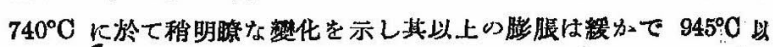

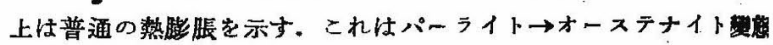

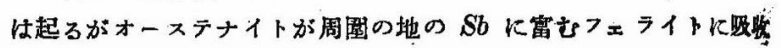
され難い事を示するので郎ち $S b$ は $\alpha$ 鐵を安定化する。

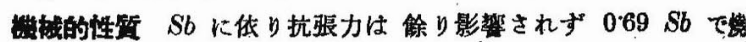

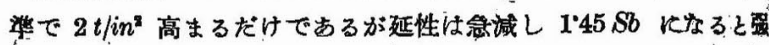

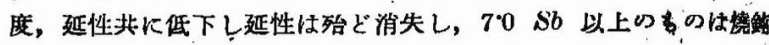

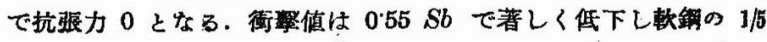

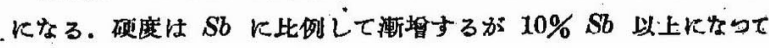
ஆ其割得さず只切㓱加工が，困難となる。

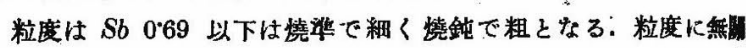

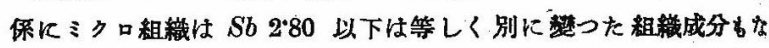

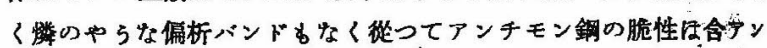

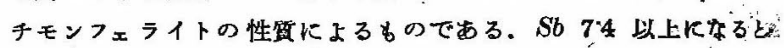
$F e S b$ の $\varepsilon$ 相务現れての $\varepsilon$ は徐冷によりフェライトの地の中に相 く析出して來る.

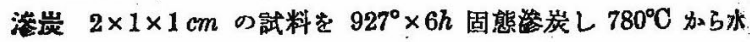

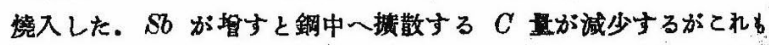

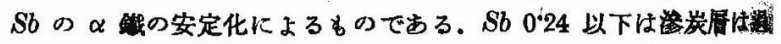
共析になり $S b \quad 0.55$ だけはフェライト十パーライトの異常組機就

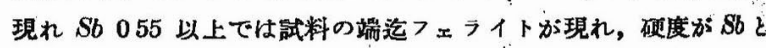

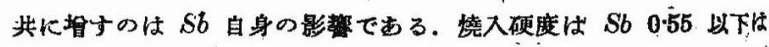

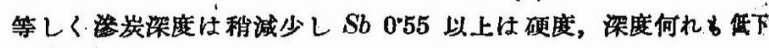
する.

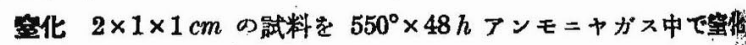

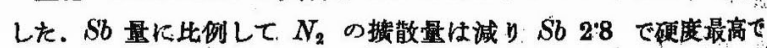

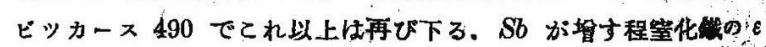

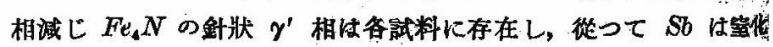
には何等役立たぬ.

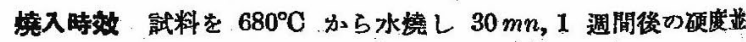
に最高時效硬度を湖定した。 560055 以下は時效硬度を㘿し，て礼

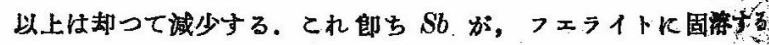

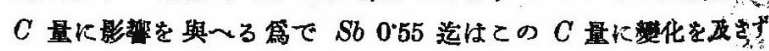

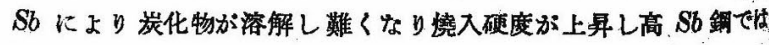
固溶炭素量が減少し時教硬化度が減少する。

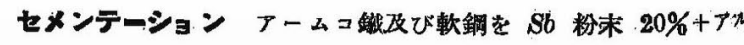
ミナ $80 \%$ の湜合制をつめた箱中で $900^{\circ} \times 3 h$ セメンテーション

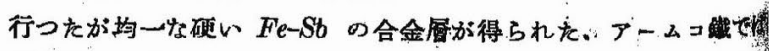

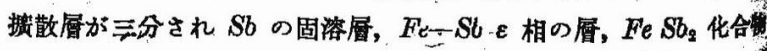

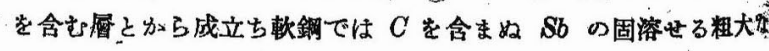

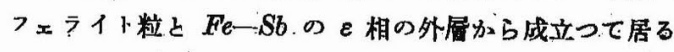




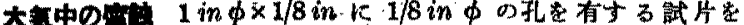

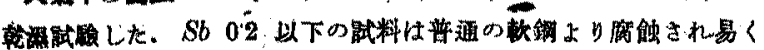

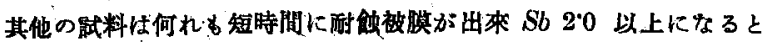

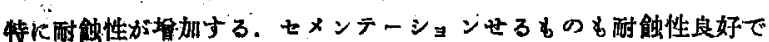
ある. 份 $\mathrm{Sb}$ は酸化に没役立を好。

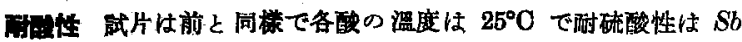

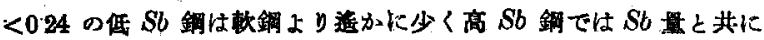

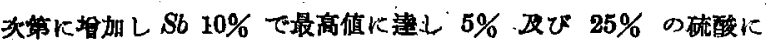
$4 h$ 後 $0.1 \sim 02 \mathrm{mg} / \mathrm{cm}^{2} 24 h$ 檬 $205 \sim 48 \mathrm{mg} / \mathrm{cm}^{2}$ で $S b$ 七メンテ ーションせる 6のはこれ以上に强く $24 h$ 後 006 0 $8 \mathrm{mg} / \mathrm{cm}^{2}$ で

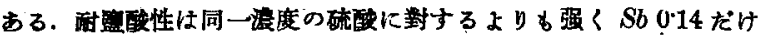

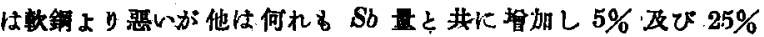

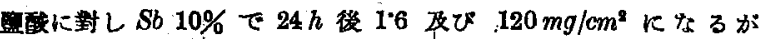

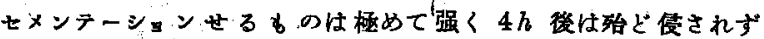

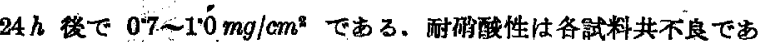

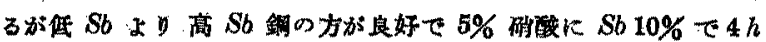

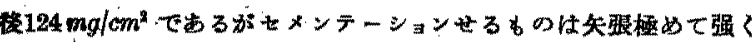

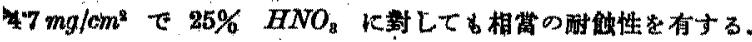

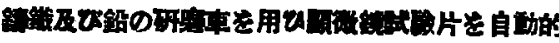
(根 守)

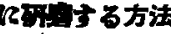

Jarrett, T. C.: Trans. A. S. M. 27 (1939) 758 766) 研磨紙

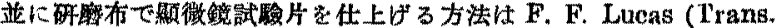
A. S. M. 24, 1936) 双び J. R. Vilella (Trans. A. S. M., 1938)

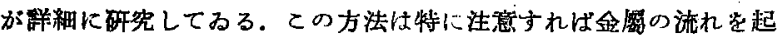

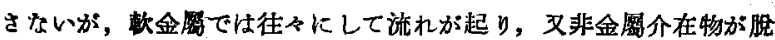
落し易い，著都の方法はか」る不都合空全く生じないるのである。 從來使用されてるる水般ア几ミナは粒度が稍大きいから，之をボー ルミルで約 2 週間磨碎し，之を水觛して使用する．各粒度に分㒕さ

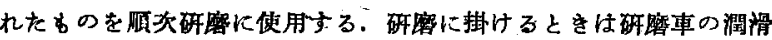

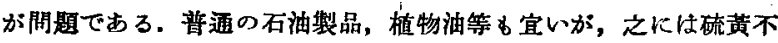

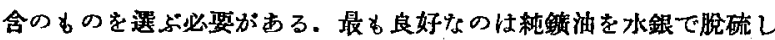

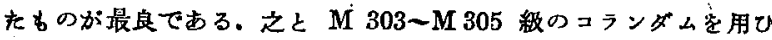

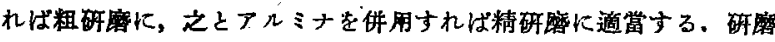
車の包轉数は 90 国 $/ m n$ が遒當である。試驗の取付はベークカ1 卜中に埋藏するがよい，通常斌驗片 6 個を仕上け゚るのに2 6hで

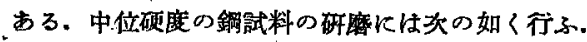

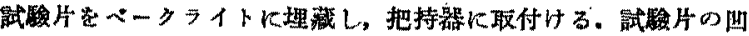

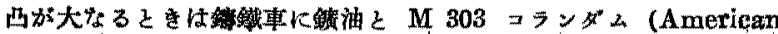

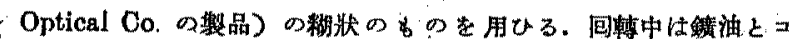

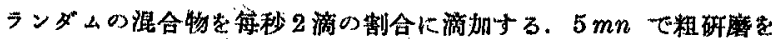
終り，次に M 305 を以で 5 mn 研磨，次に鉛車を用ひ，アルミ゙

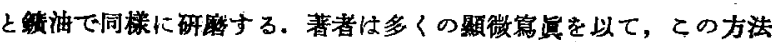
の侥䅊をととを示してるる。

(前 田)

\footnotetext{
(800 頁上りつよく)

映 南方 5000 道浬外最近 $=ニ-x$ 数䜍 (50 分間)

出席者 175 名

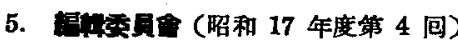

日 時 昭和 17 年 6 月 17 日（水）自午後 5 時至午後 7 時

埸 所坫會镜室。

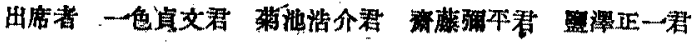

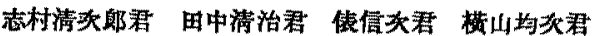

沶 第

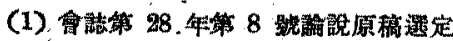

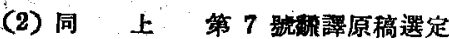

(3) 同，上 第 7 號抄錄原稿選定

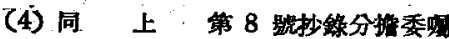

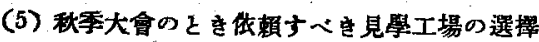

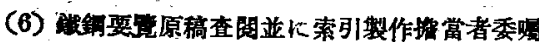

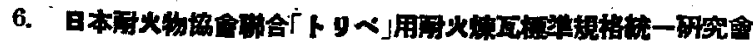

（第 10 回）

日時昭和 17 年 6 月 20 日(土) 自午後 1 時 30 分至午 後 5 時 20 分

場 所 荊究俱樂部

出席者（鲜銅㙝會側）

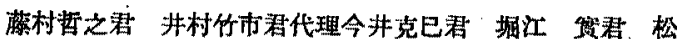

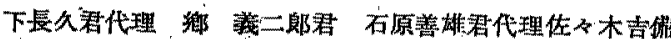
三毁君，踰木漳文君

(㳬火物㽖會僛)

黑田泰造君 永半彰一郎君 高田安雄君 毛利定男君

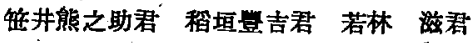

協議 亭 项

(1)「ノッッ゙ル」寸法原案修正の件

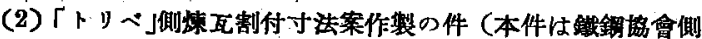
委目沙附培) 